\title{
Chapter 6 \\ Space, Marginality, and Youth in Urban Spaces: Pedagogical Practices in the Quartieri Spagnoli
}

\author{
Matías Nestore
}

This is the place with the highest number of children leaving school, the highest criminality, this place is known for having fewer green spaces than any other place in the world, an insane population density ... this place is excess on all levels. (Paola, teacher, Interview No. $8,2019)$

The Quartieri Spagnoli (QS) in Naples are a central urban area located on a slope between Via Toledo and Corso Vittorio Emanuele, two of the city's wealthiest streets. The QS are affected by high levels of disadvantage: here there are informal economies operating on crime and violence (Laino, 2012) alongside high unemployment and school dropout rates (Cavola, di Martino, \& de Muro, 2010; Laino, 2012). With the highest population density in the city, the area has a low level of basic services and poor access to green spaces, and the narrow streets restrict accessibility (Cavola et al., 2010; Laino, 2012). Their lanes form networks of relations, informal economies, and social tensions that both isolate and make this space unique. In an attempt to define the sociourban structure of the QS, Laino (2012) identified precarious labor, social deviance, immigration, dropping out from school, informal and illegal networks of activities, and exclusion as defining traits. Moreover, the area's inhabitants have seen a proliferation of youth organized crime, the socalled paranze di bambini'1 (REVES, 2016).

In this work, I seek to identify the QS as a liminal space, one that acts as both a boundary and a frontier (Balibar, 2007) that separates those who are seen as legitimate citizens from those who are constructed as illegitimate. I focus on this space as I am interested in exploring how processes of expulsion, disenfranchisement, and

\footnotetext{
${ }^{1}$ Originating from a combination of sociocultural and material deprivation, lack of social services, and schooling, the paranze di bambini or baby gangs are a growing phenomenon in the Italian South, particularly in Naples. These gangs, involving children and adolescents, lead to the proliferation of violence among youth (see Iavarone \& Girardi, 2018).
}

M. Nestore $(\bowtie)$

Homerton College, University of Cambridge, Cambridge, UK 
the complex constellations of inclusion/exclusion emerge in what might be seen as instances of Sassen's (2014) concept of urban expulsion. I have chosen the term liminal to indicate such boundaries, as well as portray such spaces as placed at the margins of North and South binaries of world development. Spaces of this kind can be understood through concepts that range from more technical notions, such as coldspots (Social Mobility Commission, 2019) or deprived neighborhoods, to more cultural and sociological ones, such as liminal spaces or sites of abjection (Wacquant, 2008).

In this chapter, I will be arguing that the QS represent a liminal space in one of the wealthiest parts of the city, made invisible by the proliferation of commercial streets, smart-city development, and neoliberal narratives of globalization and merit. In this site, children are among those who are most affected by the intersection of material inequality, violence, and sociocultural deprivation. Moreover, the QS not only represent economic marginality within the seemingly advanced global North, but also produce a number of sociocultural and historical injustices. Indeed, what is particular about the QS, and other similar urban spaces, are the ways in which historical narratives of stigma start to sediment and become embodied in the space by its people, constantly negotiating with the subjectification of marginality. Whilst inequalities and social exclusion are not new features of the urban context under study, exploring the new urban social divisions of Naples provides insight into potential sociological futures in "developed" urban realities so as to reveal and make visible the impacts of these configurations in children's lives, education paths, and futures.

In this chapter, I draw on a research project I carried out in collaboration with a school in the QS in April 2019, aimed at understanding the ways in which urban marginality, childhood, and schooling, as they are shaped by global processes, are interrelated. I constructed this empirical project with two main aims in mind: first, to enhance an understanding of liminal spaces in the Global North through the study of the QS, with a focus on the ways in which children and youth in this space relate to each other and those beyond, and who narrate their lived experiences as liminal. Second, to understand teachers' conceptualizations of their role as pedagogical actors in the QS, the nature of the pedagogies they deploy in relation to young people, and how these pedagogical acts might contribute to whether or not they are marginalized in the neighborhood. Throughout the research design, process, and analysis, I have explored the question of what constitutes childhood in liminal spaces, and what this means for education and social change.

I develop the chapter as follows: I begin by sketching out the study's theoretical underpinnings, broadly engaging with the idea of liminal spaces, youth, moral inequality, and conceptions of childhood. I then present my research's findings: the lived experiences and place-based identities of children, on the one hand, and teachers' understandings of schooling and pedagogy in marginal urban areas, on the other. I conclude by arguing that taking into account place-based identities and 
realities is fundamental for the development of educational interventions in marginalized urban areas in which children are marked by processes of cultural exclusion, social marginality, criminality, and ethnoracial tensions.

\section{Theoretical Underpinnings: Liminal Spaces, Youth, and Moral Inequality}

The QS are still seen as a ghetto, as a place on its own ... as if they were a bubble.... The children perceive that they are society's waste. (Camilla, teacher, Interview No. 9, 2019)

I want to conclude with a question: What are the spaces of the expelled? They are invisible to the standard measures of our modern states and economies. But they should be made conceptually visible. (Sassen, 2014, p. 222)

The modern development of cities, its relation to wider questions in sociology, spatial power, and its embodied narratives, cannot be detached from the experiences of those occupying and identifying with urban spaces. Sassen (2014) argues that a central issue emerging from transnational political economies of urbanization and privatization is the emergence of both novel and longstanding logics of expulsion, that is, the people, ways of life, and places that are excluded from (and by) the normative core of the socioeconomic logics of our time. This notion, in Sassen's (2014) view, takes one from the traditional idea of urban inequality (taking as a given that some are rich and some are poor) to a radical reconceptualization of urban life, in which accelerated ideals of modernity threaten society's relationship to public life and ecosystems, both denied by its most advanced and economic technical achievements.

The spaces of the expelled, which I have identified as liminal spaces, are developing across cities globally and comprise a different face of globalization and normative development (Sassen, 1991, 2005; Settis, 2019; Wacquant, 2008). Cities around the world are taking shape through three convergent forces: a verticalization of their architecture; urban sprawl; and new intra-urban borders associated with vast privatization (Settis, 2019). These three processes determine the proliferation of urban liminality, which becomes complementary to the growth of smart/resilient cities.

Balibar (2007) has defined the global proliferation of liminal spaces as the development of global banlieues. Indeed, in his work he guides the reader through the historical, political, and sociocultural segregation of those living in liminal spaces, and the ways in which the 2005 Paris uprisings were a result of a number of expulsions. Moreover, Balibar points to the docility of responses and failed resistance to the lack of recognition and social conditions of abjection experienced by the Parisian youth - something that led to a sudden explosion, or rather the implosion, of uncontrolled violence. His analysis of frontier zones in urban realities parallels Sassen's 
(1991) work on global cities, on the one hand, but also goes beyond it, on the other. Balibar introduces the experience of youth marginalization and deprivation to the discussion, reinforcing Sassen's point about young people being amongst the most affected by the condition of liminality. Balibar highlights the ways in which youth live and embody such spaces through processes of bordering and marginalization, and colonial and racial memories.

Liminal spaces take shape, not just as products of particular modes of economic governance, political projects, and material exploitation, but also as relational spaces characterized by memories, emotions, and relationships amongst people, which affects the ways in which children and youth relate to their sociocultural environment. These are spaces where normative modes of governance and traditional citizen-state relations do not exist, with people feeling more and more deprived and estranged (Rumford, 2013). Arguably, they are created and maintained through processes of the globalisation of strangeness (Dillabough \& Yoon, 2018; Rumford, 2013), and what Kearney and Taylor (2005) refer to as the sacrificial stranger. By sacrificial stranger, Kearney refers to the process of social groups defining a normative sameness based on the perversity of another group that they identify and sacrifice as a scapegoat. Rumford defines strangeness as a sense of disorientation that results from the loss of reference points that once made it easy to identify who the "we" and who the "other" were (Rumford, 2013). In Balibar's (2019) global and territorial space of "absolute capitalism," it becomes more and more difficult for people to identify as "we" with those who surround them, because they have traditions, customs, and religions that are often in conflict or at odds with the other. When people find themselves in liminal spaces where physical borders are no longer the defining feature of citizenship, they create new societal borders - through normative identities of class, race, and gender-in order to re-establish the distinctions between us and the other.

In this moment, a group affirms its identity by building a normative sameness whilst demonizing those who act differently or hold other views. The fears and anxieties caused by the feeling of strangeness, as well as a general attitude of mistrust towards the young often identified as risky or lost (Dillabough \& Kennelly, 2010), leads to experiences of exclusion amongst urban youth from disadvantaged backgrounds.

Although the conceptual tools Kearney and Taylor (2005) provide do not explicitly include spatial logics of exclusion and stigmatization, I here join them to Loïc Wacquant's (2008) work on advanced marginality so as to more fully conceptualize the liminality of space in urban realities. Indeed, liminality could be considered a condition of those residing in "sacrificial spaces," that is, the places in which the urban outcasts reside. Here they are vilified by the media (Wacquant, 2008) and ignored in the state's amelioration programs. In the same way as urban youth are deemed violent, risky, or lost, societal actors sacrifice these spaces for the sake of a normative idea of progress and development. They are sites that are "feared, fled from, and shunned" (Wacquant, 2008, p. 1). Yet these spaces are at the very center of global capital, serving as "reservoirs of low-skill labour forces, ..., warehouses 
for supernumerary populations that no longer have any identifiable political or economic utility in the new polarised capitalism ..., spatial containers for the ostracisation of social categories and activities" (Wacquant, 2008, p. 1). The QS is a liminal space in all of these senses, with the condition of advanced marginality. That these youth are children seems to disappear from view, leaving a new kind of moral inequality, both in the way children are perceived by others and in the way they perceive themselves.

You know Matías ... we would be good children if we didn't have problems. (Claudia, student, from fieldnotes, 2019)

Being able to draw the links between spatial marginalization and childhood is at the core of this work. In exploring the ways in which sociocultural forces, power dynamics, and spatial constraints determine children's conceptions of themselves and their realities, it becomes essential to understand how childhood in marginalized communities is conceptualized. Researchers of conceptualizations of childhood and inequality tend to function on the hemispheric distinction of developed and developing worlds. Hopkins and Sriprakash (2015) argue that the "... poor child at the centre of development activity is often measured against and reformed towards an idealised, globalised and normalised child subject" (p. 3). This is an embodied and normatively styled Western child, bearing the idealized traits of whiteness, masculinity, and middle-class status.

However, combining the concept of subalternity to the theories of critical childhood studies and postcolonial approaches, I wish to suggest that the idea of the subaltern child is a more useful concept to understand stigmatization, cultural violence, and disadvantage in children in subaltern conditions, both in the postcolonial world and in Western urban spaces. Hopkins and Sriprakash (2015) consider the Western child as being "unmarked by categories of difference or specificity" (p. 5), something which allows this ideal child-subject to be universalized. However, the subaltern child is marked by historically reproduced cultural stigmas, territorial fixation, and embodiment of colonial proximities (Mawani, 2009).

In the same way that the discursive dominance of the ideal Western child in development discourse affects the postcolonial child-subject framed as in need of aid and culturally deficient, the invisibility of the subaltern child within North/South dichotomies and literature furthers the reproduction of context-blindness in education and development policymaking. Given that the cultural politics of childhood can be understood as involving the struggle for redistribution, equality, and diversity (Mawani, 2009), there is an important need to frame my understanding of the subaltern child within a conceptualization of social justice and moral equality, so as to highlight the structural and cultural violence at play in the proliferation of liminality across world cities. I do so by combining an understanding of liminal spaces, spatial sociology, and subaltern childhoods with the work of Sangiovanni (2017) on moral inequality and human dignity.

Central to this analysis is the concept of social cruelty as preventing someone's ability to develop a sense of self, that is, one's conceptions of those values and 
concerns that are central to one's life, and also the understanding of the "kind of person" one is (Sangiovanni, 2017). As Sangiovanni (2017) argues:

Underpinning our practices of treating each other as moral equals, I claimed, is the rejection of social cruelty as an attack on our capacity to develop and maintain an integral sense of self, and therefore on a structural element of a flourishing life. (p. 76)

The sense of self theorized by Sangiovanni is one created through two central points of view: oneself as a creator and enactor, and oneself as created and enacted by others. When these two aspects are combined in a sense of self, it becomes integral. However, the opposite can also happen, with a subject losing control of the factors that determine their own sense of self, becoming more and more determined by external factors, actions, and forces.

The condition of childhood is one in which the construction of one's sense of self is more critical, with external factors considerably impacting on one's selfperception. Indeed, the conditions of youth and children not only reflect reality but also "produce" it. However, these conditions also "reproduce" the dominant cultural and social order, through processes of misrecognition, re-representation, and assimilation of children in certain cultural and social norms. By applying Sangiovanni's (2017) insights to the concept of subaltern childhood, it could be argued that children in urban liminal spaces are likely to have little control over the determination of their own sense of self, given that this is constantly determined by the already mentioned external factors, such as territorial fixation, violence and proximity, historical stigmatization, and cultural deprivation. This conceptualization is central to my analysis of interviews and observations.

\section{The Scuola Diffusa: Site, Scene, and Seeing}

My research design began to take shape in September 2018, during my first visit to a school in the QS, and I collected the data I present in this chapter during January and April 2019. The Scuola Diffusa, started by the social enterprise Dalla Parte dei Bambini within the FOQUS urban regeneration project, is a pedagogical initiative aimed at providing free educational opportunities to children aged 11-14 in the QS, the age with the highest rate of school abandonment in the area. Its creators aimed to include all children from the neighborhood and developed it in response to the neighborhood's high rates of school dropouts and youth criminality. They launched it as an area-based educational project in the QS, in order to complement the low degree of state educational provision. Whilst in the past the children who abandoned or were excluded from the city's state education were involved in religious educational institutions, after their closure in 2012, social enterprises or cooperatives had to fill the void, as levels of school abandonment in the neighborhood remained abnormally high. The school's curriculum is based on place-based pedagogies, aimed at helping the students engage with their own neighborhood in educational ways. This is done through using the QS, and its community, as a pedagogical 
resource: spending time talking to and learning from local artisans, shopkeepers, and farmers. Educators blend together norms of formal, informal, and experiential learning in order to provide students with a broader pedagogical experience.

The program is not intended to be limited to children with special needs or family difficulties. Rather, the aim is to actively integrate children across and beyond the QS. However, repeated processes of exclusion in the mainstream school have led to the Scuola Diffusa's demographics predominantly constituting the former. As a researcher, I am aware that this will have implicitly affected my perception of the students, as the lived reality of the classroom composition overshadowed the school's stated aims in my daily interactions and data collection. Furthermore, this understandably affects some students' perceptions of themselves and their education, with one student in particular expressing repeatedly her sense that the Scuola Diffusa taught them less than others, and her desire to move "upwards" to the mainstream school. Most students, however, stated that they enjoyed and appreciated their schooling. As such, although the students at the Scuola Diffusa may experience a particular form of alienation directly resulting from their special educational needs or behavioral challenges, the alienation with which I am dealing in this chapter stems from the physical, economic, social, and cultural marginalization of the QS as a whole.

I met the teachers at the school on my first visit, and we collaborated in designing a 2-week long pedagogical workshop. Engaging with them helped me tailor the activities to the students' characteristics, needs, and backgrounds. The aim was to design a workshop that could give the participants a chance to negotiate knowledge with the researcher while also being pedagogical.

Following Griffiths (1998), the workshop's purpose was to make the research highly collaborative, through the construction of a space of communication and joint action between the participants and the researcher. The workshop involved leaving the classroom and exploring the neighborhood with the participants through walking and talking activities. This required giving up most of my authority as researcher, given that participants were in charge of guiding me through the neighborhood, talking about the resources and issues they encountered, and taking photographs of the places they identified as matching the research's purposes.

During the course of this phase, each of the participants guided me through the QS, sharing their thoughts and perceptions as we walked along their lanes. The choice of including a photographic element in the research process was one that came about after deliberating how to represent the children's perceptions in the best possible way. The photographs were constructed collaboratively, with the participants choosing the subject and composition of the pictures. Following Pink (2013), I argue that effective use of images can help reveal the ways we experience and perceive the world, placing them at the center of how people represent and express meaning. I utilized participatory photography to capture those affective aspects of social reality that cannot be fully expressed through textual interpretation (Rose, 2007).

I used the material and fieldnotes I gathered during the workshop in the third phase of the research process as elicitation devices-that is, in the semistructured 
interviews I conducted with students and teachers. The interviews involved a total of six out of the twelve students participating in the workshops, as well as five teachers. I designed them to capture a shared moment with individual students, moments aimed at exploring their identity-management strategies, their perceptions of the QS, and the ways in which they related to the schooling and learning. I aimed my interviews with teachers at corroborating the information gathered in my fieldnotes and during the workshop, gaining knowledge about the context of the QS and the students' backgrounds, as well as collaboratively reflecting on the teachers' conceptualizations of their own roles in the neighbourhood. During the course of my time in the QS, I invested heavily in collaborating with the teachers and carried out sustained dialogue with them about the progress of my research. I used these dialogues to reimagine future methods and revise existing methods to improve the process. Such an approach allowed me to gather portraits and imagined spatial maps of the neighborhood, children's liminal experiences, and teachers' accounts of their work and their challenges. The themes I explored with the teachers during the interviews included the nature of the QS as a periphery, stigmatization, and the difficulties encountered in classrooms. I coded the interviews thematically in order to drive the analysis and identify the intersections between my experiences on the field, the students' narratives and perceptions, and the theoretical framework for the study.

\section{Identity, Schooling, and Liminality}

I derive my analysis from the stories of the children and the teachers I worked with during my time in the QS. In framing children's conceptualizations of identity, space, and liminality in the QS, in what follows I begin by exploring how children's sense of selfhood is shaped by their understanding of place, how they perceive belonging and selfhood in the QS, and the implications of the space's violence, deprivation, and stigma for the children's everyday lives. I also examine the identitymanagement strategies young people utilize as a means of everyday survival, their condition of advanced marginality, and the strategies through which they classify and reclassify themselves and others. I then turn to teachers' narrated accounts of the neighborhood and of their role as pedagogical actors. I can thus explore the links between schooling and the wider socioeconomic environment, and the ways teachers perceive their role in liminal spaces such as the QS.

\section{Violence, Stigma, and Marginality in Children's Lives}

How do these processes and relations shape identity building and spatial marginalization, so as to construct a sense of belonging and not belonging? I begin with the voices of two teachers: 
You can't disregard their stories, because they are marked by them. (Camilla, from teachers' interviews)

She [Francesca] told me about it the other day in tears- "Miss, ... I cannot understand my rage-I can't_-I don't understand — ... I can't find a way of stopping this rage, I know I'm violent and aggressive, but it's inside me and I can't-." (Paola, teacher, Interview No. 8, 2019)

Francesca, a white girl aged 12, was one of the most talkative children in the classroom, both during the workshop and during the interview. Having been personally affected by the violence — structural and physical — that characterizes the QS, she repeatedly expressed her concern for the violence in the neighborhood. Yet this did not prevent her from developing a deep attachment to the QS, proudly embodied in her ways of speaking, moving, and behaving.

F: It's as if I come to your area and I can't do anything-I'm in your territory, I'm alone. Instead, here we are all united.

M: Do you like living here?

F: Yes_-but — the Quartieri have one bad thing — they always fight ... but after all it's not a bad place. It's a place where children are always around-are always around playing — it's a nice place, it's not bad-. (Francesca, student, Interview No. 2, 2019)

Francesca's words point to the symbolic worlds that young people in the QS experience and navigate, generating ambivalent feelings towards their own realities. She describes the QS as relational, with her own experiences and memories of them forming a complex constellation of feelings and associated tensions of belongingnon-belonging. This relational understanding made it difficult for her and for other children to place the neighborhood into categorizations of good or bad, problematic or marginalized. Indeed, ambiguous experiences, feelings, and identities blended within the same spatial borders. Such findings are not atypical of other studies of youth, place, and power where advanced marginality rests at the center of such spaces (Dillabough \& Kennelly, 2010; Gulczyńska, 2019; Nayak, 2003a, 2003b).

As the activity progressed, the students identified relations, both positive and negative, as the central element giving shape to the QS. Although they referred to friendship bonds as a positive aspect of their experiences of place, violence was a recurrent element in their conceptualization of the neighborhood and their classification of its inhabitants. It was during one of these first discussions of the neighborhood that Paolo started talking about his own experiences of how he conceptualized the space and how he determined his sense of self in it. He put much weight on the violence of the space and its associated social norms of acceptance-violence here, at the edge of liminality, simply forming a part of one's experience of advanced marginality:

You're from the QS if you beat people up, and people beat you up. (Paolo, student, from fieldnotes, 2019) 
Following this group discussion, the space's relational nature emerged as important in conversation, a nature determined by violence and the embodiment of the space itself. Violence and bordering practices in the QS overlapped in the way Balibar (2007) suggests, with children remaining confined to the neighborhood-materially, culturally, and physically. These discussions were reflected in the accounts of daily experience the children recounted during the interviews.

M: What do you mean? In what sense are they [the QS] something else?

F: Because-well-wait—nothing, we have our area, and they have theirs-we only want our territory, we don't want the other one-we only need this area. (Francesca, student, Interview No. 2, 2019)

Internal bordering (Balibar, 2004) is one of the dynamics researchers have identified as characterizing liminal spaces. The children's accounts of their experiences reflected this manifestation of social exclusion, with a strong sense of territorial fixation and identification, expressed through violence, relational identities, and a feeling of spatial belonging. Moreover, internal bordering becomes not only a material or sociocultural barrier that children in the QS experience, but also an embodied border-one which, when trespassed, could result in physical violence upon them. However, this is not only a mechanism that youth in the QS passively experience, but it actively shapes their self-perception through acts of identification with the space, and acts of violent resistance. Arguably, reflecting Gramsci's (1975) take the condition of the subaltern, the liminal child furthers the effects of the decisions taken by the hegemonic class, when in the absence of other forms of control over their own selves, they reinforce marginalization through acts of violent resistance.

F: We're against each other-not us—-the boys. So the ones from here against the ones in Pallonetto [adjoining neighbourhood] — they fight—everyday.

M: Really? Why do they fight?

F: Because they shouldn't come to our area-for example if one of them comes here from the market, this is our area and we defend it. (Francesca, student, Interview No. 2, 2019)

Francesca's comment added a gendered layer to her perceptions of violence, describing girls as not being involved in inter-neighborhood youth gang violence, a predominantly male-led violence from which she indirectly suffered.

As he answered my questions during the interview, Antonio, a white boy aged 12 , kept moving around the room with the joyful energy typical of children. He was the youngest child in the class. Here he narrates an account of his embodied bordering practices in the city:

M: Alright, tell me about the street where you live.

A: I live with my friends down there, they love me, they protect me all the timeM: What do they protect you from?

A: If someone beats me up, if someone hurts me-....

M: And do you ever go to other neighborhoods?

A: I only go with my dad. 
M: So never with your friends?

A: No, otherwise we'd get beaten up-.

M: Who would beat you up?

A: Those people-from Sanità.

M: And what happens if they come here?

A: Then we beat them up-.

M: Why would you do that?

A: Because they don't have to come to our territory - this is our neighborhood-do we go to other neighborhoods? No-.

M: But don't all these neighborhoods belong to Naples?

A: No-I mean-I never leave my neighborhood. (Antonio, student, Interview No. $3,2019)$

During the course of the workshop, he repeatedly showed pride in belonging to the QS, having his close friends around him, and being able to be "above the law," or perhaps "below" it. Despite identifying illegality as one of the neighborhood's issues, he admitted that engaging in those activities was what made him a true Quartierano, ${ }^{2}$ a word he always said with a smile on his face. As Wacquant (2008) has argued, particular districts are recognized as urban abject spaces in which "...violence, vice and dereliction are the order of things" (p. 238), with social dynamics both external and internal to the space reproducing disadvantage and deprivation. Moreover, the proliferation of stigma related to place, Wacquant's (2008) territorial fixation, depends not only on vilifying discourses "from above," in journalistic, political, and bureaucratic fields, but also determines the ways in which the youth in liminal spaces develop their sense of self "from below" (p. 238), through acts of violent resistance, identification, and protest masculinity (Treadwell \& Garland, 2011). This was something the children expressed through selfidentifying as scugnizzi, and by building their place-based identities on elements such as violence, illegality, and deprivation.

The perception of territorial fixation and stigma, from both below and above, emerged in the interviews. In a thought experiment I designed for the interviews with the students, I asked them to imagine they were producing a radio program on the QS in which they had to tell people about what characterized the neighborhood. The children expressed concern about the ways those who came from "outside" misrecognized youth in the QS.

... The boys, always, they scream at them, at the tourists, at the blacks - then the tourists don't understand and they don't know how to defend themselves... They don't understand and they think we're evil. This is something that they don't have to see. This is a bad thing -.... (Francesca, student, Interview No. 2, 2019)

During a workshop session, one of the teachers highlighted this attitude of the children towards those they see as 'external' to the community. Given the ways in which the children in the QS are spectacularized as marginalized, culturally deprived, and

\footnotetext{
${ }^{2}$ Quartierano is the term used to identify someone living in the Quartieri Spagnoli, and carries a certain degree of stigma.
} 
violent, she argued that whenever they encounter someone beyond the area's borders, they act in the ways in which the tourists expect them to (from fieldnotes). This can be read as a mechanism of defence, or resistance, to hegemonic ideas about themselves, the stigmatization that comes from not being part of a normative center, both in terms of space and conceptualizations of childhood. Even if it is an act of resistance, a way of defending themselves against external spectacularization, this attitude often ended up ensuring the conflation of children's identity and legitimacy with liminality. As Wacquant (2008) also notes, when it comes to social exclusion and deprivation, "perception contributes powerfully to fabricating reality" (p. 1), with a subculture of violence, social dissolution, and marginalization proliferating across liminal spaces.

How, then, is identity managed in the context of the sacrificial stranger? Always sitting at the front of the classroom, Diego kept projecting himself outside of the QS through his statements and imagery. In my interview with him, he explicitly expressed his concern about the stigmatization the children in the QS experience, referring to violence proliferating in the space, as well as to his awareness of the problematics of childhood in the city.

D: ... I think that Naples, not that I don't like it—but I think that tourists should not come to visit it. It's a place that should not be visited.

M: How come?

D: Because I think that children with knives could hurt the tourists, with weapons, they could hurt their enemies, that is the tourists-.

M: So they should not come here-.

D: Yes. No, because if they came-they should be careful about children, if a child gets close to them, they should run away-or call someone-. (Diego, student, Interview No. 1, 2019)

In Diego's narration, there is an awareness of the condition of liminal childhood, a perception of being outside of the normative sameness that legitimizes the child as a source of innocence, tolerance, and potential (Hopkins \& Sriprakash, 2015). However, the awareness of being stigmatized, and the associated struggles for recognition, do not come without attempts to resist this negative perception. As Diego observes, this is done by avoiding the activities that he perceives as defining liminal childhood: spending time on the streets, engaging in activities at the margins of legality, and violence.

D: ... I'm never on the street, because I spend all—I spend all my days at home, I don't want to be on the street-I don't want to become a scugnizzo.

M: A scugnizzo?

D: I don't want to become like them-they drive around on mopeds, they swear-. (Diego, student, Interview No. 1, 2019)

One can attenuate an understanding of oneself as stigmatized by thrusting the stigma onto those occupying the same space as a consequence of processes of international migration (Wacquant, 2008). Migrants can become sacrificial strangers (Kearney \& Taylor, 2005) both for the children in the QS and for those in other areas 
of the city. In addition to the characteristics of sacrificial strangers presented by Kearney and Taylor (2005), the children of the QS expose ways in which they can assert their legitimacy through racial discrimination. This leads to liminal spaces becoming spaces of segmented pluralism, in other words, the hidden face of the multicultural dream, with racially marked communities from the so-called South occupying the already bordered and stigmatized spaces of the marginalized North, in turn generating subalternity, racial tensions, and violence.

Wacquant (2008) identified this as the dissolution of place, with those socially filtered place-based identities endangered by the migrant other's entry into one's own space. Throughout the interviews and the workshop activities, the children explicitly conveyed the ways they perceived their proximity with the racialized other, particularly in discussions about their understanding of the QS's community and spatial borders. This produced a complex dynamic: The children perceived themselves as scugnizzi, in other words aliens to the city's normative core, but their alienation was one that was historically and culturally legitimate when compared to that of the racialized immigrant, strategically used as sacrificial stranger in their identity management processes.

F: People of color-well that's definitely not our community, I hate them, I tell you the truth-I don't want to see them-they smell. They eat the food-I don't know, that thing they eat- - then [I hate them] because they're ugly. I don't like them. We can't stand them-we hate them too much-.

M: Why? Because of their food?

F: No no, also because of their skin color, I think. (Francesca, student, Interview No. 2, 2019)

The dissolution of place through segmented pluralism (Cohen, 2019) within an already bordered space is something that the children resisted through selfcategorization as racist, that, is the affirmation of negative perceptions of racial differences as constitutive of one's own identity, even when the children were not even sure on what basis this interracial tension developed-as something exemplified by Francesca's statement "also because of their skin color, I think" (emphasis added). Similarly, Antonio's storied account of his relations with the QS's immigrant community provided me with additional insight into this identity management strategy.

A: ... We don't want black people here-because they are black. They smell of onions-I don't like black people-.

M: Just because their skin color is different?

A: And they smell-.

M: What if they didn't smell?

A: Mmm maybe better—but I despise black people. I am racist. (Antonio, student, Interview No. 3, 2019)

It is in these spaces that external factors and social forces play a major part in children's identity-management, limiting their agency even in acts of liminal resistance, as these end up furthering marginalization, territorial fixation, and cultural 
deprivation. As the children narrate their stories, their self-categorization as quartierani and scugnizzi, as well as considering how they relate to external forces, might be the point at which valuable strategies for identifying educational interventions may emerge. Their understandings of liminal childhood, the incapacity to determine their own forms of positive agency and experiences outside of the sociocultural, material, and structural forces influencing their life-courses, are essential factors to consider when planning pedagogical interventions in liminal urban spaces.

\section{Pedagogical Landscapes in the Quartieri Spagnoli: Teachers' Perceived Roles}

How do teachers conceptualize their own roles as educators in the QS, and what are the ways in which they relate to children's stories and conceptualise pedagogy in a liminal space?

They live in an environment that keeps giving them information, wrong answers-so it's like that's pushing against us. (Paola, teacher, Interview No. 8, 2019)

I address these thematically driven stories, paying particular attention to the teachers' perspectives on pedagogy, their own role as actors in the QS, and the difficulties they face.

M: Tell me a bit about the context the school is in-.

E: So- the QS are, let's say, an anomalous periphery-they are in the heart of the city but they encompass - I mean — a big portion of social issues.... We are not a standard urban periphery, there are some aspects that are typical of the periphery but also some aspects of great transformation-they coexist in this context in a bizarre way, there is no way of integrating these two realities, they manage to coexist-let's say there is no plan or lens to understand this contamination. (Elena, teacher, Interview No. 11, 2019)

The neighborhood's anomalies were central to the teachers' narratives. Elena was the first teacher I interviewed, one of the youngest in the school. Whilst she is from a different neighborhood, she works in the primary school in the QS and could narrate the power arrangements of this space. We began the interview by exploring the neighborhood's spatial characteristics. One of the elements Elena identified is the anomalous nature of the QS, with Via Roma street acting as a border, and the physical space of the narrow lanes, in combination with institutional abandonment, creating a space for the proliferation of particular social dynamics, in this case, criminality. Elena was explicit about the power dynamics of the space and the class and race structures that determined its borders. She also identified how affluence in the globalizing city shapes these borders, giving an account of the core and periphery, defining bordering practices (Balibar, 2004) that depended not only on material wealth but also on cultural and nonmaterial poverty. Moreover, Elena identified a sort of segmented reality, with different social groups and social forces "coexisting" 
in QS, at the urban space's core, something that would disrupt normative notions of urban progress. Building on the notion of frontier and liminality, the ways in which Elena describes the QS are reflective of Balibar's (2007) idea of space as unequal, with groups of citizens with unequal rights coexisting in proximal urban realities.

Another teacher, Giulia, also identified this relational and liminal nature of place (Massey, 2005), describing the QS as follows:

The QS have these narrow lanes where you get lost—so I call them a periphery within the city ... you find Via Roma - the commercial street, with banks - and Corso Vittorio Emanuele... . In the middle there's the QS, which represent the social class which is-the lowest... I think there has been an abandonment by institutions in this context... (Giulia, teacher, Interview No. 10, 2019)

Describing the QS as a periphery within the city, an abnormal site finding its place in the metropolitan center, was a key reflection Giulia discussed. Mirroring Wacquant's (2008) description of advanced marginality, the persistence of a frontier zone, a liminal space in the urban core where migrants, deproletarized working classes, and criminality overlap, Giulia described the neighborhood in ways that provided a window for understanding the actual and symbolic violence shaping the young people's lives.

When asked about the neighborhoods' power dynamics, most teachers referred to the Camorra's ${ }^{3}$ presence influencing everyday lives in the QS. Whereas other teachers made small references to organized crime throughout their narrations, Camilla, the only non-Neapolitan teacher I collaborated with, focused on this issue more thoroughly:

Well—ehh—well obviously the perception of —of the Camorra ... people spread the news that there is a feud at that moment so there's a curfew_or there's this thing they call 'stesa' - they ride around in mopeds and shoot—. (Camilla, teacher, Interview No. 12, 2019)

Similarly, Giulia linked this presence to the negative stigmatization of the neighborhood and the people working in it:

... We are in the QS and the QS are a difficult neighborhood - a Camorra neighbourhoodand it's difficult to trust the neighborhood as a consequence-it's difficult to trust us [teachers]. (Giulia, teacher, Interview No. 10, 2019)

Building on Giulia's reflection, Anna, one of the first teachers to have joined the school, offered her thoughts on the relations between stigma, territorial fixation (Wacquant, 2008), and how the Camorra becomes a symbolic site of recognition and power even if its operatives reproduce and expand the degree of the children's marginality, alienation, and estrangement.

... They have the fear of feeling inferior, ... they think 'how can I be the same?' [as children from other neighborhoods]. This is why there's a problem with the Camorra, this is why the Camorra is attractive - there's a fine line, a wrong perception according to which it is not culture that makes you equal, so they think 'if I have money, I can be like them,' that's the whole point. (Anna, teacher, Interview No. 13, 2019)

\footnotetext{
${ }^{3}$ Camorra is the name given to organized crime in Naples.
} 
As previously mentioned, the ways in which the subaltern attempt to resist the oppression and injustices the hegemonic classes place upon them often result in practices that further those injustices (Balibar, 2007; Elsayed, 2017; Gramsci, 1975). The only strategy that children in the QS perceived of levelling the inequalities and exclusion placed upon them was not education, but rather joining networks of criminality that would allow them to gain recognition and material prosperity. On the basis of their mapping of the social, cultural, and material forces in the QS, the teachers also constructed their identities as social and political actors in the school, occupying the gap left by a State that does not engage with the children of the neighborhood. They highlighted the ways in which the school was replacing the State as provider of services and support for the children, attempting to show them alternatives to illegal strategies of recognition and material prosperity, and often offering economic support for the families.

Among other common factors across the narratives presented by teachers is the negotiation between external forces affecting children's lives, children's sense of self, and the pedagogic attempts to come to terms with the tensions between these two aspects. During the interviews, a common thread emerged of place-based pedagogical strategies as interventions in children's lives, helping them navigate the social forces and experiences that determined their identities. This also came across throughout the pedagogical workshop, with the teachers trying to upend the children's assumptions about themselves, the neighborhood, and the school's role. This was particularly evident in one of the workshop sessions in which, while discussing the QS's issues, Diego turned to the teacher and started criticizing the school:

I don't want to offend anyone but then there's these boys, those ones- the scugnizzi. I think the director of this school is wrong, they should not come to school - then of course I'm a scugnizzo too. (Diego, student, Interview No. 1, 2019)

After Diego expressed his thoughts about the school, Paola (teacher) stopped him, perceiving the tension rising in the classroom, problematizing the meaning of scugnizzo as a disadvantaged young person, and the school's role as an environment in which young people can find resources and opportunities. Moreover, she explained how succeeding in school and being from the QS need not be mutually exclusive. This exchange gave me an insight into the ways teachers explored place-based language, experiences, and identities through their pedagogical practices. Again, interpolation and ambivalence emerges about the space and its associated pedagogies. Yet teachers struggled to challenge those narratives of selfhood that further stigmatized young people, reflecting Willis's (1977/2017) findings in his seminal work.

I think, our project, which is a project that—how can I say it—doesn't make them study things that are distant from them-we have studied things very close to us, we have worked on autobiographies, on a more introspective dimension... I mean- "tell us about yourselves, question yourselves." (Paola, teacher, Interview No. 8, 2019)

Paola gave me an insight into the ways in which teachers aimed at developing pedagogic strategies to explore place-based issues, identities, and social dynamics. I believe this to be a central aspect of their pedagogy, engaging with the ways the subaltern children imagine themselves, and helping them shape that voice which is 
denied to them, acknowledging the importance of their experiences as a pedagogical tool.

Returning to Sangiovanni's (2017) conceptualization of social injustice as an attack on someone's capacity to "develop and maintain an integral sense of self" (p. 76), I found in teachers a willingness to construct pedagogical activities and provide opportunities for children to develop integral selves, helping them to negotiate the social forces that affect their lives, and giving them an opportunity to experience an alternative. This was exemplified in a number of instances, one of the most striking being a story that Giulia (teacher) told me:

... we give all children the chance to grow up, and expect something different for themselves ... this would give us Neapolitans the chance to-I feel really bad about this-the chance of getting rid of this label, this label on the QS, as being one thing-mafia—-that's what they say. (Giulia, teacher, Interview No. 10, 2019)

While exploring her pedagogical strategies and conceptualizations of liminal childhoods, Giulia gave me accounts of the conditions of advanced marginality and territorial fixation (Wacquant, 2008) experienced by the people in the QS, a sacrificial space identified as the source of society's ills. She contrasted this with the perceived effect of the school interactions, giving children "a chance to-grow up" and imagine different futures. This ideal of giving children a chance to develop their agency in determining their sense of self was also expressed by Anna, one of the first teachers to have joined the school:

What did I do when I came here? I brought them a choice, you can choose which side you want to be on, you can choose.... This is this place's [school's] mission: open up this world to the outside, open up this world that is so closed. (Anna, teacher, Interview No. 13, 2019)

The school's perceived role is to attempt to limit the social, material, and cultural forces tying the children to a particular subculture, identity, and life course. Teachers do this by exposing them to different perspectives, spaces, and role models, while also attempting to not fall into the mistake of forcing normative conceptions of childhood and models to follow that could negatively affect them too. Another interesting example of this perception of pedagogy, as well as the tensions between external social forces and the development of the children's selves, came up during my interview with Paola: "This should be the role of the school, giving young people a chance to be tolerant towards others" (Paola, teacher, Interview No. 8, 2019).

Crucially, with this statement Paola does not attempt to impose a liberal model of tolerance, or a normative sameness in which the child is innocent and as a consequence tolerant. She states that the school's role is to give "a chance to be tolerant," shifting schooling's role away from transmitting certain values and towards preventing particular spatial, cultural, and material conditions from affecting the children's identities. Drawing on Sangiovanni's (2017) notion of sense-of-self, it becomes clearer how the school's perceived objective is to provide spaces, social relations, and pedagogies that allow children to develop their internal agencies. Moreover, the teachers' vision of the school is one in which pedagogy is in dialogue with the neighborhood's broader realities, taking into account the impossibility of creating an isolated school: 
We are here to give everyone the chance to come in, because this cannot be a happy island just for children - this is a place that is in conversation with the neighborhood-the front gate is open to communicate the fact that we are here.... (Giulia, teacher, Interview No.10, 2019)

The imagined role of education as a political act, engaging in a broader dialogue with the neighborhood, takes shape through the spatial act of opening the school building's gate to outsiders, with the school courtyard as a space of integration, cultural contamination, and the creation of a new "public" sphere in the hands of civil society, with teachers carrying the burden of putting in place an intervention where the State is absent. Therefore, the proliferation of liminal spaces, necessitated by the proliferation of private capital and segregated progress, leads to a mechanism that could be defined as the privatization of social solidarity, with individuals taking over the role of providing quasi-public services. Therefore, the context of the QS could be perceived, alongside other initiatives, as a forecasting site of a privatized future, in which civil society or private organizations take on notions of social inclusion, integration, and solidarity, leading to the contradictory process of the privatization of social justice.

\section{Conclusions: Re-imagining Liminal Spaces, Pedagogies, and Subaltern Children}

The QS represent the power of liminality to define lives in the new Global North: places of contamination, segmentation, and marginality; processes rendered invisible by and engendered through the privatization of the public space, securitization, and stigmatization. Opening up possibilities for the exploration of marginalized and silenced spaces in the global North is an opportunity to illustrate the ways in which normative conceptions of progress can lead to the disintegration of the social (Sennett, 2018), violent encounters between different subaltern groups (Mawani, 2009; Wacquant, 2008), and the proliferation of forms of resistance that reproduce sociocultural oppression (Balibar, 2007). There are three key insights that can be derived from this work:

First, the children have exposed the ways in which they embody liminality and see themselves through the spatial logics of urban injustice, with territorial fixation, multicultural proximity, and violence as driving forces in their conceptualizations of identity and belonging. Returning to Sangiovanni's (2017) concept of social justice, the children's lives and their claims to selfhood and legitimacy are significantly determined by their sociocultural and economic context and narratives about them. Sangiovanni (2017) argues that this production of abjection could be considered a form of social cruelty, that is "the unauthorised, harmful, and wrongful use of another's vulnerability to attack or obliterate their capacity to develop and maintain an integral sense of self" (p. 76). This was evidenced through the children's stories and responses during the interviews and workshops, in which the verbalization of 
their identities, in attempts to resist and redefine their own conceptualizations of themselves as liminal children, was often shadowed by them reiterating the labels placed upon them by others. This points to the moral implications of capitalist forms of urban governance, driving more and more people into marginalized spaces. Striving towards more just forms of urban governance is key to hindering the exclusionary processes exposed by the children in this research project.

Second, in a space in which state institutions seem to be absent, teachers recounted ideal, sometimes imagined, pedagogies, that is the ways in which they attempted to provide children with strategies and spaces to resist those social forces that drive the construction of selfhood. These enactments are expressed in school spaces, with teachers taking on the burden of addressing the structural inequalities children face inhabiting a space that is seemingly invisible to the eyes of the State. This leaves me with questions regarding the political and pedagogical roles that civil society can play in spaces that are not only ignored by the State, but are often generated by particular dynamics of capitalist governance.

Finally, a key conclusion is that liminality will play a central role in increasing the negative consequences of macrolevel forces reshaping cities, with a crisis of modernity pushing more and more people into these spaces across the globe (Sassen, 2014). The ways in which we understand childhood and schooling in liminal spaces will necessarily involve more and more racialization and segregation, expanding lived ambiguity and the task of identity management, as well as tensions, territorial fixation, and violence in urban spaces. This will have a considerable impact on children's lives and schooling experiences, something that policymakers must necessarily take into account when designing educational interventions.

\section{References}

Balibar, É. (2004). We, the people of Europe? Reflections on transnational citizenship (J. Swenson, Trans.). Translation/Transnation: Vol. 7. Princeton, NJ: Princeton University Press.

Balibar, É. (2007). Uprisings in the Banlieues. Constellations, 14, 47-71. https://doi. org/10.1111/j.1467-8675.2007.00422.x

Balibar, É. (2019, Febuary 19). Exiles in the 21 st century: The new 'Population Law' of absolute capitalism. Presented at the Department of Development Studies, SOAS University of London, UK. Retrieved from https://www.youtube.com/watch?v=Au9ORoO7Vyk

Cavola, L., di Martino, P., \& de Muro, P. (2010). How to make neighbourhoods act? The Associazione Quartieri Spagnoli in Naples. In F. Moulaert, F. Martinelli, E. Swyngedouw, \& S. González (Eds.), Can neighbourhoods save the city? Community development and social innovation (pp. 93-104). Abingdon: Routledge.

Cohen, J. L. (2019). Populism and the politics of resentment. Jus Cogens, 1, 5-39. https://doi. org/10.1007/s42439-019-00009-7

Dillabough, J.-A., \& Kennelly, J. (2010). Lost youth in the global city: Class, culture and the urban imaginary. Critical Youth Studies: Vol. 10. New York: Routledge. https://doi. org/10.4324/9780203858332

Dillabough, J.-A., \& Yoon, E.-S. (2018). Youth geographies of urban estrangement in the Canadian city: Risk management, race relations and the 'sacrificial stranger'. Children's Geographies, 16, 128-142. https://doi.org/10.1080/14733285.2017.1334113 
Elsayed, H. (2017). La Haine: Falling in slow motion. In W. Montag \& H. Elsayed (Eds.), Balibar and the Citizen Subject (pp. 235-252). Edinburgh, UK: Edinburgh University Press.

Gramsci, A. (1975). Quaderni del carcere: Edizione critica dell'Istitutio Gramsci [Prison notebooks: Critical edition by the Gramsci Institute] (V. Gerratana, Ed.). Turin: Giulio Einaudi.

Griffiths, M. (1998). Educational research for social justice: Getting off the fence. Doing Qualitative Research in Educational Settings: Vol. 1. Buckingham, UK: Open University Press.

Gulczyńska, A. (2019). Stigma and the doomed-to-fail school careers of young people from disadvantaged neighbourhoods. Children's Geographies, 17, 413-426. https://doi.org/10.108 0/14733285.2018.1536775

Hopkins, L., \& Sriprakash, A. (2015). The 'poor child': The cultural politics of education, development and childhood. London: Routledge. https://doi.org/10.4324/9781315815336

Iavarone, M., \& Girardi, F. (2018). Poverta educativa e rischio minorile: fenomenologia di un crimine sociale [Educational poverty and juvenile risk: Phenomenology of a social crime]. Cross, 4(3), https://doi.org/10.13130/cross-10870

Kearney, R., \& Taylor, V. E. (2005). A conversation with Richard Kearney. Journal for Cultural and Religious Theory, 6(2), 17-26. Retrieved from https://jcrt.org/archives/06.2/kearney-taylor.pdf

Laino, G. (2012). Il fuoco nel cuore e il diavolo in corpo: La partecipazione come attivazione sociale [Fire in the heart and devil in the body: Participation as social activation]. Milan: Franco Angeli.

Massey, D. (2005). For space. London: Sage.

Mawani, R. (2009). Colonial proximities: Crossracial encounters and juridical truths in British Columbia, 1871-1921. Vancouver, Canada: UBC Press.

Nayak, A. (2003a). Race, place and globalization: Youth cultures in a changing world. Oxford: Berg.

Nayak, A. (2003b). 'Boyz to Men': Masculinities, schooling and labour transitions in de-industrial times. Educational Review, 55, 147-159. https://doi.org/10.1080/0013191032000072191

Pink, S. (2013). Doing visual ethnography (3rd ed.). Los Angeles: Sage.

Reverse Evaluation to Enhance Strategies. (REVES). (2016). Progetto pilota di valutazione locale studio di caso: I quartieri spagnoli di Napoli [Pilot local evaluation project for a case study: The Quartieri Spagnoli in Naples]. Retrieved from http://valutazioneinvestimenti.formez.it/ sites/all/files/1_reves_rapporto_caso_qs_na.pdf

Rose, G. (2007). Visual methodologies: An introduction to the interpretation of visual materials (2nd ed.). London: Sage.

Rumford, C. (2013). The globalization of strangeness. Basingstoke: Palgrave Macmillan. https:// doi.org/10.1057/9781137303127

Sangiovanni, A. (2017). Humanity without dignity: Moral equality, respect, and human rights. Cambridge, MA: Harvard University Press.

Sassen, S. (1991). The global city: New York, London, Tokyo. Princeton, NJ: Princeton University Press.

Sassen, S. (2005). The global city: Introducing a concept. Brown Journal of World Affairs, 11(2), 27-43. Retrieved from https://www.jstor.org/stable/24590544

Sassen, S. (2014). Expulsions: Brutality and complexity in the global economy. Cambridge, MA: Harvard University Press.

Sennett, R. (2018). Building and dwelling: Ethics for the city. London: Allen Lane.

Settis S. (2019). Diritto alla Città [The right to the city]. In I. Giuliani \& P. Piscitelli (Eds.), Città, sostantivo plurale (pp. 23-38). Milan: Fondazione Giangiacomo Feltrinelli.

Social Mobility Commission. (2019). State of the nation 2018-19: Social mobility in Great Britain. Retrieved from https://assets.publishing.service.gov.uk/government/uploads/system/uploads/ attachment_data/file/798404/SMC_State_of_the_Nation_Report_2018-19.pdf

Treadwell, J., \& Garland, J. (2011). Masculinity, marginalization and violence: A case study of the English defence league. British Journal of Criminology, 51, 621-634. https://doi.org/10.1093/ bjc/azr027 
Wacquant, L. (2008). Urban outcasts: A comparative sociology of advanced marginality. Cambridge: Polity.

Willis, P. E. (2017). Learning to labour: How working class kids get working class jobs (With a foreword by S. Aronowitz). New York, NY: Columbia University Press. (Original work published 1977)

Open Access This chapter is licensed under the terms of the Creative Commons Attribution 4.0 International License (http://creativecommons.org/licenses/by/4.0/), which permits use, sharing, adaptation, distribution and reproduction in any medium or format, as long as you give appropriate credit to the original author(s) and the source, provide a link to the Creative Commons license and indicate if changes were made.

The images or other third party material in this chapter are included in the chapter's Creative Commons license, unless indicated otherwise in a credit line to the material. If material is not included in the chapter's Creative Commons license and your intended use is not permitted by statutory regulation or exceeds the permitted use, you will need to obtain permission directly from the copyright holder.

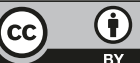

